\title{
PENERAPAN MODEL PEMBELAJARAN KOOPERATIF TIPE MATCH MINE UNTUK MENINGKATKAN KEMAMPUAN KOMUNIKASI MATEMATIS SISWA KELAS VII DI MTs NEGERI 2 MEDAN
}

\author{
Doriyani Nasution \\ FMIPA, Unimed Medan \\ nasution.riri@gmail.com \\ Izwita Dewi \\ Dosen Matematika FMIPA, Unimed Medan.
}

\begin{abstract}
This study aims to improve students' mathematical communication skills through the application of cooperative learning model Match Mine on the subject of integers in classVII MTs2 Medan. This type of researchis a classroom action research. The subjects were students of class VII-1 MTs 2 Terra in TA 2014/2015 which amounted to 42students. The object of this research is the students' mathematical communication skills through cooperative learning model Match Mine on the subject of integers. The research instrument used is th eobservation and test mathematical communication skills. This study consisted two cycles and at the end of each cycleis given test comunication is mathematical ability. Before given, test first validated to the validator. The results showed that cooperative learning model in the material Match Mine integer scan improve students' mathematical communication. It is seen from the results before action is given, the provisi on of diagnostics tests of 42 students only as many as 15 students (35.72\%), which reached a value $\geq 65$ with an average value of 58.18 class. After agiven action, the first mathematical communication skills tests in the first cycle, from 42 students as many as 25 students (59.52\%) reached a value $\geq 65$ with an average value of 66.95 class. From theanalysis ofthe test data communication capabilities mathematicalI on the second cycle of 42 people found that the students are 37 students (88.09\%) reached a value $\geq 65$ with an average value of 74.38 class. Based on observation, learning management research conducted in the first cycle, including both categories with a scoreof 2.87. Furthermore, in the second cycle, the researcher's ability to manage the learning increased to 3.40 so very good category. Based on the above results, it can be conclude edthatby implementing cooperative learning model Match Mine can improve students' mathematica lcommunication on the subject of integers in class VII MTs 2 Medan. Suggestions submitted to the seventh grade math teacher at MTs Negeri 2 Medan advis able to provide training to students that many require students to provide arguments that students' mathematical communication skills especially in explaining aspect scan be increased, as well asprovide the opportunity for students express ideas/ideas verbally/ writing in the learning process, andusing learning model
\end{abstract}

Keywords : mathematical communication, communication, secondary school, classroom action research, match mine.

\section{PENDAhUluan}

Perkembangan ilmu pengetahuan dan teknologi merupakan salah satu acuan dasar sebuah ilmu pengetahuan dikatakan berkembang dengan pesat. Perkembangan ilmu pengetahuan dan teknologi memudahkan kita untuk berkomunikasi dan memperoleh berbagai informasi dengan cepat dari berbagai belahan dunia(Ansari, 2009:1).Perkembangan tersebut memberikan wahana yang memungkinkan matematika

Doriyani Nasution, Izwita Dewi. 2015. Penerapan Model Pembelajaran Kooperatif Tipe Match Mine untuk Meningkatkan Kemampuan Komunikasi Matematis Siswa Kelas VII di MTs Negeri 2 Medan T.A. 2014/2015. Inspiratif. Vol. 1 No. 1, hal 96-111 
berkembang dengan pesat pula. Matematika merupaan ilmu universal yang mendasari perkembangan teknologi modern dan penting dalam berbagai disiplin ilmu serta mampu mengembangkan daya pikir manusia. Bagi dunia keilmuan, matematika memiliki peran sebagai bahasa simbolik yang memungkinkan terwujudnya komunikasi secara cermat dan tepat. Dapat dikatakan bahwa perkembangan pesat di bidang teknologi dan komunikasi dewasa ini dilandasi oleh perkembangan matematika. Penguasaan matematika yang kuat sejak dini diperlukan siswa untuk menguasai dan menciptakan teknologi masa depan. Oleh karena itu, mata pelajaran matematika perlu diajarkan di setiap jenjang pendidikan untuk membekali siswa dengan mengembangkan kemampuan menggunakan bahasa matematika dalam mengkomunikasikan ide atau gagasan matematika untuk memperjelas suatu keadaan atau masalah.

Salah satu isu penting dalam pembelajaran matematika saat ini adalah pentingnya pengembangan kemampuan komunikasi matematis siswa. Pengembangan komunikasi juga menjadi salah satu tujuan pembelajaran matematika dan menjadi salah satu standar kompetensi lulusan dalam bidang matematika. Melalui pembelajaran matematika, siswa diharapkan dapat mengkomunikasikan gagasan dengan simbol, tabel, diagram, atau media lain untuk memperjelas keadaan atau masalah sesuai dengan Permendiknas Nomor 20 tahun 2006 tentang Standar Isi (Wijaya, 2012:16).

Pentingnya kemampuan komunikasi dan pemahaman matematika perlu dilatihkan kepada siswa, didukung oleh visi pendidikan matematika yang mempunyai dua arah perkembangan yaitu memenuhi kebutuhan masa kini dan masa yang akan datang (Sumarmo, dalam Tandiling, 2012).

$$
\text { Tandiling (2012) mengatakan }
$$

bahwa:"Visi pertama untuk kebutuhan masa kini, pembelajaran matematika mengarah pada pemahaman konsep-konsep yang diperlukan untuk menyelesaikan masalah matematik dan ilmu pengetahuan lainnya. Visi kedua untuk kebutuhan masa yang akan datang atau mengarah ke masa depan, mempunyai arti lebih luas yaitu pembelajaran matematika memberikan kemampuan nalar yang logis, sistematis, kritis, dan cermat serta berpikir objektif dan terbuka yang sangat diperlukan dalam kehidupan sehari-hari serta untuk menghadapi masa depan yang selalu berubah."

Rendahnya kemampuan siswa dalam matematika juga tidak terlepas dari kemampuan guru dalam mengajar siswanya. Sebagian guru kurang tepat memilih metode yang digunakan untuk menyampaikan materi pelajaran. Umumnya guru masih menggunakan cara konvensional dalam pembelajaran dimana guru lebih berperan aktif sebagai pemberi pengetahuan dan siswa hanya mendengarkan penjelasan yang disampaikan oleh guru sehingga siswa jarang berkomunikasi dalam pembelajaran.Kebanyakan guru matematika hanya menekankan pada penguasaan materi semata dan lebih banyak menjalin komunikasi satu arah dengan siswanya (teacher center).

Turmudi (2009:7) mengungkapan bahwa:"Siswa tidak diberi kesempatan untuk mengemukakan idenya, menyampaikan gagasannya, bahkan untuk mengomentari kesalahan penyajian sekalipun. Siswa yang terlalu banyak 'omong' bahkan 'diancam' oleh gurunya, nanti kamu nilainya jelek, kamu nanti tidak naik kelas. Kondisi seperti ini akan menghasilkan siswa yang tertutup, siswa yang pasif dan siswa yang penakut.”. Sunyoto dan Fitriatien (2011) juga mengungkapkan:"Pelaksanaan pembelajaran pada umumnya guru masih menerapkan pembelajaran yang bersifat konvensional yang pada tahap pelaksanaan pembelajarannya dimulai dari menjelaskan materi, memberikan contoh dan dilanjutkan dengan latihan soal, sehingga pembelajaran cendrung berpusat pada guru. Keadaan demikian mengakibatkan siswa menjadi pasif karena siswa kurang diberi kebebasan untuk mengungkapkan ide-ide dan pendapat yang dimilikinya. Jarang sekali guru mengelompokkan siswa dalam kelompok belajar, sehingga kurang terjadi interaksi

Doriyani Nasution, Izwita Dewi. 2015. Penerapan Model Pembelajaran Kooperatif Tipe Match Mine untuk Meningkatkan Kemampuan Komunikasi Matematis Siswa Kelas VII di MTs Negeri 2 Medan T.A. 2014/2015. Inspiratif. Vol. 1 No. 1, hal 96-111 
antara siswa dengan siswa ataupun siswa dengan guru."

Hal tersebut juga didapati oleh penulis ketika melakukan observasi di kelas VII-1 MTs Negeri 2 Medan yang dilakukan pada hari kamis 10 april 2014 dimana guru bidang studi matematika tersebut masih menggunakan model pembelajaran konvensional sehingga pembelajaran belum berpusat pada siswa (student centered learning). Guru menyiapkan siswa untuk memulai pelajaran lalu guru mengingatkan kembali siswa tentang materi sebelumnya. Pada saat itu materi yang akan dijelaskan guru adalah sudut oleh karena itu, guru kembali menjelaskan mengenai garis, kedudukan dua garis, sifat-sifat garis sejajar dan lain sebagainya. Metode yang digunakan oleh guru tersebut masih sebatas pada metode ceramah dimana guru hanya menjelaskan materi sementara siswa tidak diberikan kesempatan untuk menyampaikan atau mengkomunikasikan ide atau gagasannya melaluli lisan sehingga siswa menjadi tidak aktif selama kegiatan pembelajaran matematika.Maka, dengan kondisi yang demikian bagaimana guru dapat mengembangkan kemampuan komunikasi siswa apabila guru tidak memberikan kesempatan dan waktu kepada siswa untuk mengkomunikasikan idenya. Karenannya pemberian kesempatan kepada siswa dan mendengarkan ide-ide siswa akan menjadi kata kunci tercapainya kemampuan komunikasi.

Dari hasil observasi tersebut, dapat disimpulkan bahwa:

1. Guru masih menggunakan model pembelajaran konvensional sehingga kegiatan pembelajaran di MTs Negeri 2 Medan masih terpusat pada guru yang mengakibatkan siswa menjadi pasif dan tidak leluasa dalam menyampaikan ideidenya.

2. Guru lebih menekankan terhadap penguasaan materi, bukan pada komunikasi matematis siswa.

3. Siswa tidak aktif dalam belajar matematika selama kegiatan pembelajaran berlangsung.
Pada materi bilangan bulat kebanyakan siswa menganggap materi tersebut adalah materi yang sulit karena kurangnya pemahaman siswa mengenai materi bilangan bulat ketika berada di Sekolah Dasar, Padahal pokok bahasan bilangan bulat merupakan pengetahuan dasar yang harus dikuasai oleh siswa tingkat SMP karena berhubungan dengan materi yang akan dipelajari selanjutnya.

Dari 42 orang siswa yang melakukan tes diagnostik dengan persentase ketuntasan klasikal $35,72 \%$ terdapat $45,23 \%$ siswa yang memperoleh skor dibawah kategori minimal sedang yaitu $\leq 65$ untuk aspek menggambar, $42,85 \%$ siswa yang memperoleh skor $\leq 65$ untuk aspek membaca gambar, 83,33\% siswa yang memperoleh skor $\leq 65$ untuk aspek menjelaskan, dan $66,66 \%$ siswa yang memperoleh skor $\leq 65$ untuk aspek representasi. Dari data tersebut dapat diketahui bahwa kemampuan komunikasi matematis siswa terutama pada aspek menjelaskan masih rendah sehingga perlu ditingkatkan.

Untuk meningkatkan kemampuan komunikasi matematis siswa, perlu dirancang suatu model pembelajaran yang membiasakan siswa untuk mengkonstruksi sendiri pengetahuannya dan yang dapat mendukung serta mengarahkan siswa pada kemampuan untuk berkomunikasi matematis. Salah satunya adalah model pembelajaran kooperatif tipe match mine dimana model pembelajaran ini belum pernah diterapkan di MTs Negeri 2 Medan khususnya di kelasVII1. Hal ini diketahui penulis dengan menanyakannya secara langsung dengan guru bidang studi yang bersangkutan. Model pembelajaran kooperatif tipe match mine ini merupakan salah satu tipe pembelajaran kooperatif yang dicetuskan oleh pakar pendidikan Spencer Kagan, Ia menyatakan dalam artikelnya yang berjudul "The Structural Approach to Cooperative Learning" bahwa model pembelajaran kooperatif tipe match mine ini merupakan pembelajaran yang dapat membangun komunikasi (communication building).

Doriyani Nasution, Izwita Dewi. 2015. Penerapan Model Pembelajaran Kooperatif Tipe Match Mine untuk Meningkatkan Kemampuan Komunikasi Matematis Siswa Kelas VII di MTs Negeri 2 Medan T.A. 2014/2015. Inspiratif. Vol. 1 No. 1, hal 96-111 
Jadi tujuan penelitian ini adalah ntuk meningkatkan kemampuan komunikasi matematis siswa melalui penerapan model pembelajaran kooperatif tipe match minepada pokok bahasanbilangan bulat kelas VII MTs Negeri 2 Medan T.A 2014/2015 dan mengetahui aspek yang paling dominan dan paling minimal dalam peningkatan kemampuan komunikasi matematis siswa.

\section{Kemampuan Berpikir Matematis}

Kemampuan berpikir matematis telah dikembangkan di Jepang sejak sekitar 45 tahun yang lalu (Katagiri, dalam Wijaya, 2012:13). Kegiatan berpikir matematis dilandasi oleh dua pasang proses fundamental, yaitu: spesialisasi dan generalisasi serta pendugaan dan penegasan (Mason, Burton, dan Stacey dalam Wijaya, 2012:13). Proses generalisasi merupakan bagian yng esensial dari berpikir matematis. Proses generalisasi dapat didefinisikan sebagai sebarang himpunan $\mathrm{X}$ yang dapat digeneralisasikan ke Y. Sebagai contoh proses mendapatkan rumus-rumus matematika adalah merupakan proses generalisasi (Hudojo, 2005:66). Dalam pembelajaran matematika terdapat perbedaan antara "melakukan matematika" dengan berpikir matematis". Noyes (dalam Wijaya, 2012:11) mengungkapkan bahwa proses latihan cenderung mengarahkan pada melakukan matematika sedangkan proses mendidik sebaikanya diarahkan pada berpikir secara matematis. Untuk memahami perbedaan antara "melakukan matematika" dengan "berpikir matematis", kita bisa melihat matematika dari tiga sudut pandang, yaitu: (1) posisi matematika, (2) aspek matematika, (3) jenis pengetahuan matematika.

\section{Komunikasi}

Istilah komunikasi berasal dari kata Latin Communicare atau Communis yang berarti sama atau menjadikan milik bersama (Ambarjaya, 2012:110). Komunikasi merupakan proses penyampaian ide dari seseorang kepada orang lain sehingga diperoleh pengertian yang sama. Makna lain dari komunikasi yang terdapat dalam kamus Inggris-Indonesia berarti hubungan. Dalam kamus bahasa Indonesia disebutkan bahwa komunikasi merupakan pengiriman dan penerimaan pesan atau berita antara dua orang atau lebih sehingga pesan yang dimaksud dapat dipahami.

Berikut ini beberapa definisi komunikasi (dalam Ambarjaya 2012:110).

a. Komunikasi adalah kegiatan pengoperan lambang yang mengandung arti atau makna yang perlu dipahami bersama oleh pihak yang terlibat dalam kegiatan komunikasi.

b. Komunikasi adalah kegiatan perilaku atau kegiatan penyampaian pesan atau informasi tentang pikiran atau perasaan.

c. Komunikasi adalah sebagai pemindahan informasi dan pengertian dari satu orang ke orang lain.

d. Komunikasi adalah berusaha untuk mengadakan persamaan dengan orang lain

e. Komunikasi adalah penyampaian dan memahami pesan dari satu orang kepada orang lain, komunikasi merupakan proses sosial

Berdasarkan uraian diatas yang dimaksud komunikasi dalam penelitian ini adalah proses penyampaian ide dari pengirim pesan kepada penerima pesan dengan tujuan tertentu sehingga diperoleh pengertian yang sama.

\section{Kemampuan Komunikasi Matematis}

Penyampaian ide-ide ataupun gagasan mengunakan simbol-simbol, notasi-notasi dan lambang-lambang merupakan salah satu kemampuan komunikasi matematis. Menurut sumarmo (dalam Alam, 2011) kemampuan komunikasi dalam matematika merupakan kemampuan yang dapat menyertakan dan memuat berbagai kesempatan untuk berkomunikasi dalam bentuk :

(1) merefleksikan benda-benda nyata, gambar, dan diagram kedalam ide matematika; (2) membuat model situasi atau persoalan menggunakan metode lisan, tertulis, konkrit, grafik, dan aljabar;

Doriyani Nasution, Izwita Dewi. 2015. Penerapan Model Pembelajaran Kooperatif Tipe Match Mine untuk Meningkatkan Kemampuan Komunikasi Matematis Siswa Kelas VII di MTs Negeri 2 Medan T.A. 2014/2015. Inspiratif. Vol. 1 No. 1, hal 96-111 
menyatakan peristiwa sehari-hari dalam Bahasa atau symbol matematika; (4) mendengarkan, berdiskusi, dan menulis tentang matematika; (5) membuat konjektur, menyusun argumen, merumuskan definisi, dan generalisasi; (6) menjelaskan dan membuat pertanyaan tentang matematika yang telah dipelajari; (7) mengungkapkan kembali suatu uraian paragrap dalam Bahasa sendiri.

Kemampuan komunikasi matematis (mathematical communication) dalam pembelajaran matematika sangat perlu untuk dikembangkan. Hal ini karena melalui komunikasi matematis siswa dapat mengorganisasikan berpikir matematisnya baik secara lisan maupun tulisan. Di samping itu, siswa juga dapat memberikan respon yang tepat antar siswa dan media dalam proses pembelajaran. Bahkan dalam pergaulan bermasyarakat, seseorang yang mempunyai kemampuan komunikasi yang baik akan cenderung lebih mudah beradaptasi dengan siapa pun dimana dia berada dalam suatu komunitas, yang pada gilirannya akan menjadi seorang yang berhasil dalam hidupnya. Komunikasi matematis perlu menjadi fokus perhatian dalam pembelajaran matematika, sebab melalui komunikasi, siswa dapat mengorganisasi dan mengkonsolidasi berpikir matematisnya, dan siswa dapat meng-explore ide-ide matematika (Umar, 2012).

\section{Membangun Kemampuan Komunikasi Matematis}

Aktivitas guru yang dapat menumbuhkembangkan kemampuan komunikasi matematis siswa menurut Soekisno (2008) antara lain :

1. Mendengarkan dan melihat dengan penuh perhatian ide-ide siswa

2. Menyelidiki pertanyaan dan tugastugas yang diberikan, menarik hati, dan menantang siswa untuk berpikir

3. Meminta siswa untuk merespon dan menilai ide mereka secara lisan dan tertulis
4. Menilai kedalaman pemahaman atau ide yang dikemukakan siswa dalam diskusi

5. Memutuskan kapan dan bagaimana untuk menyajikan notasi matematika dalam bahasa matematika siswa

6. Memonitor partisipasi siswa dalam diskusi, memutuskan kapan dan bagaimana untuk memotivasi masing-masing siswa untuk berpartisipasi

Siswa sejak dini juga hendaknya banyak diperkenalkan soal-soal yang terkait dengan kemampuan komunikasi matematis siswa. Soal-soal yang disampaikan setidaknya dapat menggugah siswa untuk menyelesaikan permasalahan dengan model yang dikembangkan siswa sendiri. Tentu saja penjelasan dengan gambar dan diagram mutlak diperlukan jika siswa mengalami kesulitan dalam membahaskan hasil pemikiran siswa. Nizar (2010) mengungkapkan kriteria-kriteria terkait dengan soal-soal komunikasi matematis dan salah satunya yaitu soal yang meminta siswa untuk menyajikan suatu pernyataan matematika baik lisan, tertulis, gambar maupun diagram.

Dalam hal ini guru memiliki peran yang penting dalam membangun kemampuan komunikasi matematis siswa karena guru merupakan perancang kegiatan pembelajaran di kelas. Guru dapat menggunakan komunikasi lisan maupun tulisan untuk memberikan kesempatan siswa dalam berpikir, menyusun pertanyaan-pertanyaan, memberikan penjelasan, menemukan notasinotasi baru, bereksperimen dalam bentuk argumentasi, dan merefleksikan pemahaman mereka dengan ide-ide orang lain.

Indikator Kemampuan Komunikasi
Matematis
Indikator kemampuan komunikasi
matematis merupakan suatu acuan
kompetensi komunikasi matematika dapat
tercapai atau tidak. Indikator-indikator untuk
mengukur kemampuan komunikasi
matematis yang diutarakan oleh beberapa
pakar diantaranya yaitu:

Doriyani Nasution, Izwita Dewi. 2015. Penerapan Model Pembelajaran Kooperatif Tipe Match Mine untuk Meningkatkan Kemampuan Komunikasi Matematis Siswa Kelas VII di MTs Negeri 2 Medan T.A. 2014/2015. Inspiratif. Vol. 1 No. 1, hal 96-111 
Sumarmo mengungkapkan indikatorindikator komunikasi matematis (dalam Husna,dkk, 2013) yaitu :

1. Mengubungkan benda nyata, gambar dan diagram kedalam ide matematika.

2. Menjelaskan ide, situasi dan relasi matematika, secara lisan/tulisan dengan benda nyata, grafik, dan diagram.

3. Menyatakan peristiwa sehari-hari dalam bahasa atau simbol matematika.

4. Mendengarkan, berdiskusi, dan menulis tentang matematika.

5. Membaca dengan pemahaman suatu prosentasi matematika tertulis.

6. Membuat konjektur, menyusun argumen, merumuskan definisi dan generalisasi

Sedangkan menurut NCTM (dalam Husna, dkk, 2013) indikator kemampuan komunikasi matematis, yaitu :

1. Kemampuan mengekspresikan ideide matematis melalui lisan, tulisan dan mendemonstrasikannya serta menggambarkannya secara visual.

2. Kemampuan memahami, mengiterpretasikan, mengevaluasi ide-ide matematis baik secara lisan, tulisan, maupun dalam bentuk visual lainnya.

3. Kemampuan dalam menggunakan istilah-istilah, notasi-notasi matematika dan struktur-strukturnya untuk menyajikan ide-ide, menggambarkan hubungan-hubungan dengan model-model situasi.

Indikator Komunikasi tertulis dibatasi pada kegiatan komunikasi model Cai, Lane, dan Jakabein (dalam Ansari, 2009:5) yang meliputi:

1. Menulis matematika : pada kemampuan menulis matematika siswa dituntut dapat menulis penjelasan dari jawaban permasalahannya secara matematis, masuk akal dan jelas, serta tersusun secara logis dan sistematis.

2. Menggambar matematika : pada kemampuan menggambar matematika siswa mampu melukis gambar, diagram, grafik, dan tabel secara lengkap dan benar.

3. Ekspresi matematika : pada kemampuan ekspresi matematika siswa mampu memodelkan matematika dengan benar, kemudian melakukan perhitungan atau mendapat solusi secara lengkap dan benar.

Merujuk dari uraian diatas, indikator komunikasi matematis yang digunakan dalam penelitian ini adalah :

1. Merefleksikan ide-ide matematika maupun solusi matematika ke dalam bentuk gambar, diagram, grafik dan tabel.

2. Merefleksikan gambar, diagram, grafik dan tabel ke dalam ide-ide matematika maupun solusi matematika.

3. Menyatakan ide matematika menggunakan simbol-simbol atau bahasa matematika secara tertulis ke bentuk model matematika.

4. Menjelaskan suatu masalah dengan memberikan argumentasi terhadap permasalahan matematika dan menarik kesimpulan serta memberikan alasan atau bukti terhadap kebenaran solusi.

\section{Pembelajaran Kooperatif Tipe Match} Mine

Match mine dalam pembelajaran Kooperatif di gagas oleh Spencer Kagan dalam karyanya StructuralApproach to Cooperative Learning tahun 1989 (Kagan, 1989). Ia menegaskan bahwa match mine merupakan pembelajaran yang dapat membangun keterampilan berkomunikasi atau "communication building". Secara sederhana, match mine dapat diartikan bahwa siswa mencoba menyesuaikan/menyamakan susunan objek kisi-kisi siswa lain dengan menggunakan komunikasi lisan maupun tulisan (Sharan, dalam Latifa, 2011).

Model pembelajaran kooperatif tipe match mine dapat membangun keterampilan berpikir matematis dan keterampilan berkomunikasi. Pembelajaran kooperatfi tipe match mine ini memungkinkan siswa untuk :

Doriyani Nasution, Izwita Dewi. 2015. Penerapan Model Pembelajaran Kooperatif Tipe Match Mine untuk Meningkatkan Kemampuan Komunikasi Matematis Siswa Kelas VII di MTs Negeri 2 Medan T.A. 2014/2015. Inspiratif. Vol. 1 No. 1, hal 96-111 
- Mengorganisasi dan mengembangkan kemampuan berpikir matematis siswa melalui komunikasi.

- Mengomunikasikan hasil pemikiran matematis siswa secara koheren dan jelas kepada rekan, guru dan lainnya.

- Menganalisa dan menilai hasil pemikiran matematis dari orang lain.

- Menggunakan bahasa matematika untuk mengekspresikan ide-ide matematis dengan tepat (Kagan, 2009:5).

Permainan match mine memberikan banyak keuntungan bagi siswa diantaranya:

(1) mengembangkan kosakata matematika,

(2) meningkatkan kemampuan komunikasi verbal, (3) meningkatkan kemampuan untuk mengarahkan, (4) memelihara keterampilan bekerja sama, (5) mengembangkan kemampuan menganalisa secara visual, (6) menambah perbendaharaan kata (Kagan,2009:8).

Grifin (2010) menjelaskan langkahlangkah dalam pembelajaran kooperatif tipe match mine, yaitu :

1. Bentuklah siswa menjadi grup-grup yang berpasangan

2. Tiap grup terdapat penghalang diantara keduanya sehingga mereka tidak dapat melihat meja tulis mereka.

3. Tiap siswa dalam grup menerima lembar diskusi

4. Orang pertama sebagai "penyampai". Mengacu pada lembar diskusi, ia menjelaskan sebuah gambar, ide, atau klu kepada "penerima" pada lembar diskusi, sehingga si "penerima" dapat menggambarkan atau menyamakan idenya dengan si "penyampai".

5. Setelah selesai, mereka secara bergantian bertukar posisi Orang pertama yang pada awal sebagai "penyampai" menjadi "penerima", dan sebaliknya.

6. Mereka mendiskusikan hasilnya.

Miguel Kagan menjelaskan match mine yang diterapkan untuk tingkat pendidikan dasar yaitu "penyampai" meletakkan objek pada papan yang telah disediakan, kemudian ia memberikan clue kepada "penerima". "Penerima" berusaha meletakkan objek pada papan yang serupa dengan "penyampai" (Kagan, 2009:6).

Dengan model pembelajaran kooperatif tipe match mine ini siswa secara aktif mengungkapkan ide-idenya, menjelaskan gagasan yang diberikan temannya dan berdiskusi untuk menyamakan idenya tersebut. Kagan (dalam Latifa, 2011) menjelaskan lebih lanjut definisi dari pembelajaran kooperatif tipe match mine itu sendiri. Terdapat 2 aktifitas pembelajaran kooperatif tipe match mine, yaitu:

1. Draw What I say, siswa memberi suatu perintah kepada siswa lainnya untuk menggambar apa yang dijelaskan olehnya. Siswa menyajikan matematika dengan gambar/diagram berdasarkan clue yang diberikan pasangannya. Dalam proses ini, sebelum nya siswa pertama menyampaikan ide atau gagasanay, ia terlebih dahulu menggambarkan idenya atau gagasannya. Kemudian ia sampaikan atau merefleksikan gambar (ide) nya secara lisan sehingga siswa kedua dapat membuat suatu gambar yang sama atau memiliki satu gagasan yang sama dengan teman pertama. Setelah selesai, keduanya mendiskusikan hasilnya. Sedangkan Griffin (2010) menjelaskan pengertian dari Draw What I say "Describe to them the picture that will be shown, so they can create one to match".

2. Build What I Write; Didalam proses ini siswa memberikan ide-idenya secara tertulis. Ide-ide tersebut dapat berupa gambar, grafik, tabel, permasalahan matematika dalam kehidupan sehari-hari dan sebagainya. Misalnya siswa pertama memberikan suatu gambar kepada pasangannya kemudian teman pasangannya atau siswa kedua membangun ide yang diberikan oleh temannya kemudian menjelaskannya secara rinci maksud dari ide yang diberikan oleh temannya dengan bahas lisan atau tertulis kepada siswa pertama. Siswa mengkomunikasikan secara matematik berdasarkan apa yang di

Doriyani Nasution, Izwita Dewi. 2015. Penerapan Model Pembelajaran Kooperatif Tipe Match Mine untuk Meningkatkan Kemampuan Komunikasi Matematis Siswa Kelas VII di MTs Negeri 2 Medan T.A. 2014/2015. Inspiratif. Vol. 1 No. 1, hal 96-111 
gambar oleh pasangannya (dalam bentuk tabel, diagram dll). Setelah selesai, keduanya berdiskusi untuk menyamakan ide yang dimaksud tersebut.

\section{Kerangka Konseptual}

Pembelajaran kooperatif tipe match mine ini menstimulus kemampuan komunikasi matematis siswa baik lisan maupun tertulis. Kemampuan komunikasi matematis adalah kemampuan siswa dalam merefleksikan gambar, tabel, grafik kedalam ide-ide matematika, memberikan penjelasan ide, konsep, atau situasi matematika dengan bahasa sendiri dalam bentuk penulisan secara matematik dan menyatakan peristiwa seharihari dalam bahasa atau simbol matematika. Kemampuan komunikasi matematis merupakan bagian dari kemampuan dasar yang harus dimiliki siswa.

Pembelajaran kooperatif tipe match mine dapat menjadikan siswa secara aktif memberikan gagasan-gagasan yang dimiliki siswa, dapat menggali potensi dan kompetensi yang terpendam yang dimiliki siswa, dapat merefleksikan suatu gambar, grafik atau tabel kedalam ide-ide matematika serta dapaat menyelesaikan masalah seharihari yang erat kaitannya dengan matematika.

Berdasarkan uraian diatas, maka penulis menggunakan model pembelajaran kooperatif tipe match mine yang dapat memberikan kontribusi bagi pengembangan kemampuan komunikasi matematika siswa.

\section{Hipotesis Penelitian}

Berdasarkan kerangka konseptual yang telah diuraikan, maka yang menjadi hipotesis tindakan dari penelitian ini adalah:bahwa penerapan model pembelajaran kooperatif tipe match minedapat meningkatkan kemampuan komunikasi matematik siswa MTs Negeri 2 Medan di kelas VII-1.

\section{METODE PENELITIAN \\ Lokasi dan Waktu Penelitian}

Penelitian ini dilaksanakan di MTs Negeri 2 Medan. Sedangkan waktu penelitian ini dilaksanakan pada semester I (Ganjil) Tahun Ajaran 2014/2015.

\section{Subjek Penelitian}

Subjek penelitian ini adalah siswa kelas VII-1 MTs Negeri 2 Medan yang berjumlah 42 orang yang diambil satu kelas secara acak dari 9 kelas yang ada untuk keseluruhan kelas VII.

\section{Objek Penelitian}

Objek dalam penelitian ini adalah meningkatkan kemampuan komunikasi matematis siswa melalui pembelajaran kooperatif tipe match mine pada materi bilangan bulat di MTs Negeri 2 Medan Tahun Ajaran 2014/2015.

\section{Defenisi Operasional.}

Agar tidak terjadi kesalahan penafsiran terhadap penelitian ini, makapeneliti mendefinisikan beberapa istilah berikut ini:

1. Komunikasi matematis merupakan cara siswa untuk menyampaikan ide-ide atau gagasan yang dimilikinya untuk memecahkan suatu permasalahan yang diberikan.

2. Kemampuan komunikasi matematis merupakan kemampuan siswa untuk menyampaikan ide-ide atau gagasan yang dimilikinya untuk memecahkan suatu permasalahan yang diberikan.

3. Match Minemerupakan sebuah model pembelajaran yang memberikan kesempatan kepada siswa untuk mengkomunikasikan ide atau gagasannya secara tertulis dan dilakukan oleh siswa secara berpasangan untuk menyelesaikan soal-soal yang terkait dengan pembelajaran.

\section{Jenis Penelitian}

Jenis penelitian ini adalah penelitian tindakan (action research). Penelitian tindakan adalah suatu proses yang dilalui oleh perorangan atau kelompok yang menghendaki perubahan dalam situasi tertentu untuk menguji prosedur yang diperkirakan akan menghasilkan perubahan tertentu dan kemudian, setelah sampai pada tahap kesimpulan yang dapat dipertanggungjawabkan (Tim Dosen, 2013:25). Penelitian ini akan menjelaskan tentang upaya meningkatkan kemampuan komunikasi matematis siswa melalui model pembelajaran kooperatif tipe match mine dari

Doriyani Nasution, Izwita Dewi. 2015. Penerapan Model Pembelajaran Kooperatif Tipe Match Mine untuk Meningkatkan Kemampuan Komunikasi Matematis Siswa Kelas VII di MTs Negeri 2 Medan T.A. 2014/2015. Inspiratif. Vol. 1 No. 1, hal 96-111 
hasil tes kemampuan komunikasi matematis siswa.

\section{Prosedur Penelitian}

Sesuai dengan jenis penelitian ini, yaitu penelitian tindakan kelas makapenelitian ini memiliki beberapa tahap yang merupakan suatu siklus. Setiap siklus dilaksanakan sesuai dengan perubahan yang akan dicapai. Pada penelitian ini jika siklus pertama tidak berhasil, yaitu tes kemampuan komunikasi siswa I belum mencapai ketuntasan belajar, maka dilaksanakan siklus II dan siklus akan berhasil jika kemampuan komunikasi matematis siswa mencapai ketuntasan belajar secara klasikal. Dalam penelitian ini direncanakan hanya sampai 2 siklus saja, dan tiap siklus terdiri dari tiga kali pertemuan.

\section{Siklus I}

\section{Permasalahan I}

Permasalahan diperoleh dari tes diagnostik yang telah dilakukan peneliti. Telah ditemukan beberapa kesulitan yang dihadapi siswa dalam menyelesaikan soalsoal kemampuan komunikasi matematis siswa dan untuk mengelompokkan siswa ke dalam kelompok belajar.

\section{Perencanaan Tindakan I}

Tahap perencanaan tindakan I dilakukan setelah tes diagnostik diberikan. Tes diagnostik yang dilakukan bertujuan untuk mengetahui kemampuan komunikasi matematis siswa. Hasil tes ini kemudian digunakan sebagai acuan dalam membagi siswa menjadi beberapa kelompok belajar. Pada tahap perencanaan tindakan ini, hal yang dilakukan adalah:

a. Menyusun rencana pelaksanaan pembelajaran (RPP) untuk pertemuan 1, 2, dan 3 pada siklus I yang disesuaikan dengan model pembelajaran kooperatif tipe match mine.

b. Mempersiapkan sarana pendukung pembelajaran yang mendukung pelaksanaan tindakan, yaitu membuat lembar kerja siswa (LKS) serta lembar diskusi match mine.

c. Mempersiapkan instrumen penelitian, yaitu menyusun lembar evaluasi akhir untuk pertemuan, menyusun kisi-kisi soal evaluasi akhir untuk pertemuan, menyusun lembar observasi siswa dan guru.

\section{Pelaksanaan Tindakan I}

Setelah perencanaan tindakan I disusun dengan matang, maka tahap selanjutnya adalah pelaksanaan tindakan I, yaitu sebagai berikut:

a. Melakukan pembelajaran dengan menerapkan model pembelajaran kooperatif tipe match mine berdasarkan rencana pelaksanaan pembelajaran (RPP) yang telah disusun peneliti. Dimana peneliti bertindak sebagai guru, sedangkan guru MTs Negeri 2 Medan bertindak sebagai pengamat yang akan memberi masukan selama pembelajaran sedang berlangsung.

b. Pada akhir tindakan I siswa diberikan tes kemampuan komunikasi matematis tulisan siswa untuk melihat apakah ada peningkatan kemampuan komunikasi matematis siswa dengan menerapkan model pembelajaran kooperatif tipe match mine.

c. Memberikan kesempatan kepada siswa untuk melakukan tanya jawab tentang soal yang diberikan dan tentang materi yang kurang dipahami.

\section{Observasi I}

Observasi dilakukan bersamaan dengan pelaksanaan tindakan. Dalam hal ini observasi yang dilakukan ada dua yaitu :

\section{Observasi Terhadap Guru}

Observasi dilakukan oleh salah satu guru di MTs Negeri 2 Medan untuk memberi masukan terhadap pembelajaran yang sedang berlangsung. Observasi kegiatan terhadap peneliti yang dalam hal ini bertindak sebagai guru, meliputi :

a. Keterampilan membuka pelajaran

b. Menyajikan materi dengan menerapkan model pembelajaran kooperatif dengan teknik Match Mine.

c. Melibatkan siswa dalam pembelajaran.

d. Berkomunikasi dengan siswa

e. Mengelola waktu dan model pembelajaran.

f. Menutup pelajaran.

\section{Observasi Terhadap Siswa}

Doriyani Nasution, Izwita Dewi. 2015. Penerapan Model Pembelajaran Kooperatif Tipe Match Mine untuk Meningkatkan Kemampuan Komunikasi Matematis Siswa Kelas VII di MTs Negeri 2 Medan T.A. 2014/2015. Inspiratif. Vol. 1 No. 1, hal 96-111 
Observasi terhdap siswa bertujuan untuk melihat kegiatan belajar siswa dalam pembelajaran dengan menggunakan model pembelajaran kooperatif tipe Match Mine. Observasi ini dilakukan oleh peneliti dan guru MTs Negeri 2 Medan. Observasi ini meliputi:

a. Komunikasi siswa dalam memperhatikan penjelasan guru.

b. Komunikasi siswa dalam diskusi kelompok.

c. Komunikasi dan keberanian siswa dalam mengajukan soal/permasalahan,

d. Kemampuan siswa terhadap pembahasan hasil diskusi kelompok.

e. Kemampuan komunikasi siswa dalam menyelesaikan soal secara benar.

\section{Analisis Data I}

Analisis data dilakukan melalui tiga tahap, yaitu reduksi data, paparan data, dan penyimpulan.

\section{- Reduksi}

Data yang diperoleh direduksi agar itu lebih sederhana dengan cara menyeleksinya dengan mengelompokkan data-data dalam beberapa kategori kemudian mengorganisasikannya sehingga diperoleh informasi yang bermakna. Kegiatan bertujuan untuk melihat kelemahan siswa selama dalam pembelajaran dan tindakan apa yang dilakukan untuk memperbaiki kelemahan siswa.

- Paparan Data

Setelah data direduksi, maka data tersebut dipaparkan dalam bentuk paparan naratif agar data tersebut lebih jelas dan mudah dipahami.

- Penyimpulan

Dalam kegiatan ini ditarik beberapa kesimpulan berdasarkan hasil penelitian yang dilakukan.

\section{Refleksi I}

Tahap ini dilakukan untuk mengambila keputusan perencanaan tindakan selanjutnya berdasarkan hasil analisis data dari pemberian tindakan pada siklus I yang mencakup :

- Tidak tercapainya ketuntasan belajar siswa dalam menguasai materi bilangan bulat.

- Hasil observasi terhadap guru dan siswa

Kesimpulan yang diambil kemudian digunakan sebagai dasar untuk tahap perencanaan yang akan dilakukan pada siklus II.

\section{Siklus II}

Bila hasil perbaikan yang diharapkan belum tercapai pada siklus I, maka tindakan masih perlu dilanjutkan pada siklus II. Pada siklus II diadakan perencanaan kembali dengan mengacu pada hasil refleksi pada siklus I. Siklus II merupakan hasil kesatuan dari kegiatan perencanaan, pelaksanaan tindakan, observasi dan analisis, serta refleksif seperti yang dilakukan pada siklus I.

\section{Instrumen dan Alat Pengumpulan Data}

Dalam penelitian ini digunakan alat pengumpulan data, yaitu tes kemampuan komunikasi matematis dan observasi.

\section{- Tes Kemampuan Komunikasi}

Tes yang digunakan adalah tipe uraian, agar proses berfikir siswa dapat dievaluasi dan untuk menghindari siswa menajwab secara menebak. Tes ini digunakan untuk mengukur adanya peningkatan kemampuan komunikasi matematik siswa. Tes ini terdiri dari tes awaldan tes kemampuan komunikasi siswa. Data yang didapat dari pelaksanaan tes awal digunakan sebagai acuan dalam pengelompokkan siswa dengan kriteria kemampuan komunikasi sangat tinggi, tinggi, sedang, rendah, dan sangat rendah.

Ada beberapa hal yang perlu diperhatikan oleh peneliti sebelum menyusun naskah tes, yaitu :

- Menentukan ruang lingkup pertanyaan.

- Menyusun kisi-kisi tes

- Dalam kisi-kisi tampak ruang lingkup materi yang disajikan, bentuk soal, dan jumlah soal.

- Menyusun soal berdasarkan kisi-kisi yang telah dibuat.

- Membuat penyelesaian soal.

Setelah tes disusun, maka dilanjutkan dengan validitas tes, apakah tes tersebut mengungkapkan isi suatu konsep atau

Doriyani Nasution, Izwita Dewi. 2015. Penerapan Model Pembelajaran Kooperatif Tipe Match Mine untuk Meningkatkan Kemampuan Komunikasi Matematis Siswa Kelas VII di MTs Negeri 2 Medan T.A. 2014/2015. Inspiratif. Vol. 1 No. 1, hal 96-111 
variabel yang hendak diukur (validitas isi). Untuk mencari validitas tes yang dimaksud diminta penilaian kepada tiga orang yang dianggap paham untuk menvalidasi tes tersebut. Seperti yang diungkapkan oleh Djaali dan Mujiono (dalam Nurhasanah, 2013): "Penentuan proporsi validitas isi didasarkan pendapat (judgement) para ahli dalam bidang yang bersangkutan".

Dengan demikian, validitas isi tidak memerlukan uji coba atau analisis statistik dalam bentuk angka - angka. Ketiga orang validator diminta tanggapannya terhadap perangkat tes tersebut, antara lain:

- Tanggapan mengenai kesesuaian antara indikator pembelajaran dengan soal yang dibuat.

- Atas ketetapan hal tersebut, validator diminta menentukan tiap butir soal kedalam kategori dapat valid $(\mathrm{V})$, dapat dilaksanakan valid revisi (VR), tidak valid (TV).

\section{Observasi}

Observasi yang dilakukan merupakan pengamatan terhadap seluruh kegiatan dan perubahan yang terjadi pada saat dilakukannya pemberian tindakan. Dalam hal ini guru bidang studi matematika bertindak sebagai pengamat (observer) yang bertugas untuk mengobservasi peneliti (yang bertindak sebagai guru) melalui lembar observasi yang telah disediakan dengan tujuan mengetahui keterlaksanaan kegiatan pembelajaran didalam pelaksanaan model pembelajaran kooperatif tipe match mine di MTs Negeri 2 Medan.

$P_{i}=\frac{\text { jumlah seluruh aspek yang diamati }}{\text { bany akny aaspek y ang diamati }}$

\section{Teknik Analisis Data}

Analisis data dalam penelitian ini dilakukan dalam beberapa tahap yaitu :

\section{- Reduksi Data}

Setelah tes kemampuan komunikasi matematis siswa mengenai bilangan bulat diberikan, selanjutnya diberikan koreksi hasil peketjaan siswa, dipelajari dan ditelaah untuk menggolongkan dan mengorganisasikan jawaban siswa. Setelah data dikelompokkan kemudian dilanjutkan papa penyimpulan. Kegiatan reduksi ini bertujuan untuk melihat kesalahan jawaban siswa dan permasalahan yang dialami siswa dalam menyelesaikan soal dan tindakan apa yang dilakukan untuk perbaikan kesalahan tersebut.

\section{- Interpretasi Hasil}

a. Tingkat Penguasaan Siswa

Dari hasil jawaban siswa maka akan diperoleh gambaran pencapaian hasil belajar. Menurut Wayan Nurkancana (dalam Nurhasanah, 2013:50) bahwa kategori penguasaan siswa adalah sebagai berikut:

Tabel Tingkat Penguasaan Siswa

\begin{tabular}{|c|l|}
\hline $\begin{array}{c}\text { Tingkat } \\
\text { Penguasaan }\end{array}$ & \multicolumn{1}{c|}{ Kriteria } \\
\hline $90 \%-100 \%$ & $\begin{array}{l}\text { Kemampuan } \\
\text { sangat tinggi } \\
\text { Kemampuan } \\
\text { tinggi }\end{array}$ \\
$80 \%-89 \%$ & $\begin{array}{l}\text { Kemampuan } \\
\text { sedang } \\
\text { Kemampuan } \\
\text { rendah } \\
\text { Kemampuan } \\
\text { sangat rendah }\end{array}$ \\
\hline 5
\end{tabular}

Tingkat kemampuan siswa menyelesaikan soal ditentukan dengan kriteria penentuan tingkat penguasaan siswa terhadap materi yang diajarkan. Dengan demikian untuk mengetahui tingkat penguasaan siswa digunakan rumus:

$P P H=\frac{S P}{S M} \times 100 \%$

hasil belajar

$$
\mathrm{PPH}=\text { Presentase pencapaian }
$$

SP = Skor yang diperoleh siswa

$\mathrm{SM}=$ Skor Maksimal

Tingkat penguasaan siswa akan terlihat pada tinggi rendahnya skor mentah yang dicapai. Tingkat penguasaan siswa dapat dilihat dari persentase pencapaian hasil belajar siswa per-pertemuan dan persentase pencapaian hasil belajar setelah materi selesai atau persentasi hasil. Tingkat penguasaan siswa tercapai apabila siswa mencapai tingkat penguasaan dengan kriteria sedang.

\section{b. Ketuntasan Belajar Individu}

Doriyani Nasution, Izwita Dewi. 2015. Penerapan Model Pembelajaran Kooperatif Tipe Match Mine untuk Meningkatkan Kemampuan Komunikasi Matematis Siswa Kelas VII di MTs Negeri 2 Medan T.A. 2014/2015. Inspiratif. Vol. 1 No. 1, hal 96-111 
Dari skor tes komunikasi matematis yang diperoleh siswa di hitung ketuntasan belajar secara individual. Ketuntasan belajar siswa secara individul dihitung dengan rumus

$$
K B=\frac{B}{N} \times 100 \%
$$

Keterangan :

$$
\begin{array}{ll}
\mathrm{KB} & =\text { Ketuntasan belajar } \\
\mathrm{B} & =\text { Jumlah skor yang } \\
& \text { diperoleh siswa } \\
\mathrm{N} & =\text { Jumlah skor total } \\
\text { (sumber : } & \text { Trianto, } 2011: 241 \text { ) }
\end{array}
$$

Adapun kriteria ketuntasan belajar siswa dapat diukur sebagai berikut :

$0 \% \leq K B<65 \% \quad$ Siswa belum tuntas belajar

$65 \% \leq K B \leq 100 \% \quad$ Siswa tuntas belajar

\section{Ketuntasan Belajar Klasikal}

Selanjutnya dapat juga diketahui apakah ketuntasan belajar secara klasikal telah tercapai, dilihat dari persentase siswa yang sudah tuntas dalam belajar dapat digunakan rumus sebagai berikut:

$$
\begin{aligned}
& P K K \\
& =\frac{\text { Banyak Siswa yang } K B \geq 65}{\text { Banyak Subjek Penelitian }}
\end{aligned}
$$

Dimana :

PKK : Persentase Ketuntasan Klasikal

Seorang siswa dikatakan tuntas jika $K B \geq 65 \%$ sedangkan suatu kelas dikatakan tuntas jika PKK $\geq 85 \%$.

\begin{tabular}{|l|l|c|l|}
\hline No. & \multicolumn{1}{|c|}{ Aspek } & Hasil & $\begin{array}{l}\text { Kriteria } \\
\text { Keberhasilan }\end{array}$ \\
\hline 1. & $\begin{array}{l}\text { Ketuntasan } \\
\text { Belajar }\end{array}$ & Tuntas & $\begin{array}{l}\geq 85 \% \\
\text { menjawab } \geq \\
65 \% \text { benar }\end{array}$ \\
\hline 2. & $\begin{array}{l}\text { Kegiatan } \\
\text { Siswa dalam } \\
\text { Komunikasi } \\
\text { matematika }\end{array}$ & Baik & $\begin{array}{l}>50 \% \\
\text { Kategori Baik }\end{array}$ \\
\hline 3. & $\begin{array}{l}\text { Kemampuan } \\
\text { guru dalam } \\
\text { mengolah } \\
\text { pembelajaran }\end{array}$ & Baik & $\begin{array}{l}\text { Nilai rata- } \\
\text { rata } \geq 2,2-3,1 \\
\text { kategori baik }\end{array}$ \\
\hline
\end{tabular}

\section{c. Menganalisis Hasil Observasi \\ Pembelajaran \\ 1. Observasi guru}

Dari hasil observasi yang telah
dilakukan

dilakukanpenganalisisandengan

menggunakan rumus:dimana $P_{i}$ : hasil pengamatan pada pertemuan ke-IAdapun kriteria rata-rata penilaian observasi adalah:

Tabel Kriteria Hasil Observasi Pembelajaran

\begin{tabular}{|c|c|}
\hline Skor & $\begin{array}{c}\text { Kriteria Proses Belajar } \\
\text { Mengajar }\end{array}$ \\
\hline $0-1,1$ & Sangat Buruk \\
\hline $1,2-21$ & Buruk \\
\hline $2,2-3,1$ & Baik \\
\hline $3,2-4,0$ & Sangat Baik \\
\hline
\end{tabular}

(diadaptasi dari Nurhasanah, 2013)

Pembelajaran dikatakan efektif jika hasil pengamatan observer, pembelajan termasuk dalam kategori baik atau sangat baik.

\section{Observasi Siswa}

Adapun perhitungan persentase data hasil observasi kemampuan komunikasi matematis peserta didik selama mengikuti pembelajaran adalah sebagai berikut

$$
R S=\frac{\text { Jumlah Skor }}{\text { Skor Mkasimal }} \times 100 \%
$$

Dimana $: \mathrm{RS}=$ persentase rerata skor

Nilai RS selanjutnya diberikan penafsiran berdasarkan interval dan kriteria yaitu :

Tabel Interpretasi Komunikasi Siswa

\begin{tabular}{|c|c|}
\hline Interval SR & Kriteria \\
\hline $75 \%<\mathrm{RS} \leq$ \\
$100 \%$ & Sangat Baik \\
\hline $\begin{array}{c}50 \%<\mathrm{RS} \leq \\
75 \%\end{array}$ & Baik \\
\hline $\begin{array}{c}25 \%<\mathrm{RS} \leq \\
50 \%\end{array}$ & Cukup \\
\hline $\mathrm{RS} \leq 25 \%$ & Kurang \\
\hline
\end{tabular}

\section{Kriteria dan Target Keberhasilan}

Adapun kriteria (target) keberhasilan yang digunakan untuk menghentikan atau melanjutkan siklus dalam penelitian ini dilihat dari aspek-aspek sebagai berikut :

Doriyani Nasution, Izwita Dewi. 2015. Penerapan Model Pembelajaran Kooperatif Tipe Match Mine untuk Meningkatkan Kemampuan Komunikasi Matematis Siswa Kelas VII di MTs Negeri 2 Medan T.A. 2014/2015. Inspiratif. Vol. 1 No. 1, hal 96-111 
Keterangan :

1. Terpenuhi kriteria ketuntasan belajar, yaitu setiap siswa (individu) menjawab benar $\geq 65 \%$, tuntas klasikal jika $\geq 85 \%$ siswa tuntas belajar.

2. Terpenuhi kriteria komunikasi siswa yang baik dalam pembelajaran.

3. Tingkat kemampuan guru menyelenggarakan proses pembelajaran minimal kategori baik.

Apabila salah satu dari 3 kriteria keberhasilan yang sudah di tetapkan di atas tidak dipenuhi maka penelitian ini dilanjutkan pada siklus berikutnya dengan memperhatikan hasil refleksi dan memperbaiki kekurangan serta kelemahan yang terjadi pada siklus sebelumnya.

\section{Paparan Data}

Data-data yang telah diklarifikasikan tersebut kemudian dipaparkan menurut jenis masalah penelitian. Pemaparan data dilakukan dengan menampilkan satuansatuan informasi secara sistematis. Dengan adanya pemaparan informasi itu, peneliti akan dapat menarik kesimpulan dengan mudah. Untuk memperjelas analisis, data peneliti tersebut dipaparkan dalam bentuk naratif dan dilengkapi dengan tabel.

\section{Penarikan Kesimpulan}

Dalam kegiatan ini ditarik beberapa kesimpulan berdasarkan hasil peneliti yang telah dilakukan. Kesimpulan yang diambil merupakan dasar bagi pelaksanaan siklus berikutnya dan perlu tindakan siklus dilajutkan atas permasalahan yang diduga.

Dalam penelitian ini, kemampuan komunikasi matematis siswa dikatakan meningkat jika ada pertambahan nilai ratarata kemampuan komunikasi matematis pada tiap aspek komunikasi matematis dari tes kemampuan komunikasi matematis siswa setelah pembelajaran dengan model pembelajaran match mineyang diberikan setiap siklusnya, serta bertambahnya presentase banyak siswa yang memiliki kemampuan komunikasi matematis dengan kriteria minimal sedang.

\section{HASIL DAN PEMBAHASAN}

\section{Kemampuan Komunikasi Matematis Siswa}

Berdasarkan hasil tes kemampuan komunikasi matematis siswa siklus I dan siklus II diketahui bahwa nilai rata-rata tes dari 66,95 menjadi 74,38 , dan ketuntasan belajar klasikal dari 59,52\% menjadi 88,09\%. Adapun kategori peningkatan komunikasi matematis siswa pada siklus I berkategori rendah dan pada siklus II berkategori tinggi. Dari hasil tes tersebut terlihat bahwa terjadi peningkatan hasil tes kemampuan komunikasi matematis siswa.

Peningkatan komunikasi matematis siswa pada penelitian ini terjadi sebagai imbas dari kemampuan guru dalam melaksanakan pembelajaran kooperatif tipe Match Mine dan penggunaan LKS yang membantu siswa untuk meningkatkan kemampuan komunikasinya. Dengan menerapkan model pembelajaran kooperatif tipe Match Mine siswa yang bertindak sebagai pasangan penyampai gagasan dapat memberikan ide-idenya secara tertulis, kemudian siswa yang bertindak sebagai penerima gagasan membangun ide yang diberikan oleh temannya dengan menyelesaikan soal Match Mine sesuai dengan klu-klu yang diberikan pasangan penyampai. Siswa secara bergantian bertukar peran sebagai pemberi ide dan penerima ide yang diberikan temannya. Setelah keduanya selesai menjelaskan secara tertulis konsep yang terkait dengan apa yang yemannya tulis kedua pasangan tersebut berdiskusi untuk menyamakan ide yang dimaksud tersebut. Proses diskusi yang dilakukan oleh siswa, dipantau dan dimonitori oleh guru atau peneliti sehingga peneliti dapat memberikan motivasi dan mengarahkan siswa jika terdapat siswa yang tidak menanggapi ide atau menilai apa yang dikemukakan temannya secara tertulis. dengan menggunakan model pembelajaran kooperatif tipe Match Mine ini dapat memberikan banyak kesempatan kepada siswa untuk berinteraksi menyampaikan ide-idenya, merefleksikan gagasan yang diberikan temannya dan berdiskusi menyamakan idenya. Adanya diskusi telah menciptakan

Doriyani Nasution, Izwita Dewi. 2015. Penerapan Model Pembelajaran Kooperatif Tipe Match Mine untuk Meningkatkan Kemampuan Komunikasi Matematis Siswa Kelas VII di MTs Negeri 2 Medan T.A. 2014/2015. Inspiratif. Vol. 1 No. 1, hal 96-111 
komunikasi verbal antar siswa dimana siswa saling berbagi ide dan gagasan dalam menyampaikan pendapatnya dengan katakata sesuai dengan pemahaman mereka dan membandingkannya dengan pendapat temannya tanpa harus takut membuat kesalahan dalam mengerjakan soal.

Hasil ini juga didukung oleh penelitian yang dilakukan oleh Latifa (2011) dengan judul penelitian Pengaruh Model Pembelajaran Kooperatif Tipe Match Mine Terhadap Kemampuan Komunikasi Matematik Siswa. Hasil penelitiannya menunjukkan bahwa rata-rata komunikasi matematis siswa kelas eksperimen lebih tinggi dibandingkan dengan rata-rata kemampuan komunikasi siswa kelas kontrol. Selain itu Spencer Kaga pun menegaskan bahwa model pembelajaran kooperatif tipe match mine merupakan "communication building". Tipe match mine ini lebih menekankan pencapaian kemampuan komunikasi matematis siswa dalam prosesnya siswa mencocokkan ide dengan teman pasangannya melalui Build What I Write. Kemmapuan komunikasi matematis terkait dengan written text, menunjukkan bahwa siswa mampu menjelaskan secara rinci masalah matematika dengan menggunakan bahasa sendiri dalam penulisannya secara matematik.

Dari hasil penelitian ini diketahui juga bahwa kategori peningkatan komunikasi matematis siswa pada siklus I berkategori rendah dan pada siklus II berkategori tinggi. Hasil ini sejalan dengan penelitian Ansari(2004) yang menyatakan pada umumnya kemampuan komunikasi matematis siswa sangat rendah. Rendahnya kemampuan komunikasi matematis ini setidaknya disebabkan oleh faktor lamanya siswa dalam belajar menggunakan pembelajaran kooperatif tipe Match Mine dan faktor tingkat kesukaran soal komunikasi matematis siswa yang digunakan pada penelitian ini untuk mengukur kemampuan komunikasi matematis siswa.

Dalam penelitian ini ada 4 aspek yang telah diukur peningkatannya dari siklus I dan II. Berdasarkan tes kemampuan komunikasi matematis siswa diperoleh peningkatan ratarata nilai siswa pada masing-masing aspek untuk siklus I dan II sebagai berikut:

Tabel Peningkatan nilai rata-rata siswa pada ke 4 aspek dari siklus I dan siklus II

\begin{tabular}{|l|l|l|}
\hline Aspek & Siklus I & Siklus II \\
\hline Menggambar & $\begin{array}{l}75,00 \\
\text { (sedang) }\end{array}$ & $\begin{array}{l}80,65 \\
\text { (tinggi) }\end{array}$ \\
\hline Membaca Gambar & $\begin{array}{l}78,81 \\
\text { (sedang) }\end{array}$ & $\begin{array}{l}82,98 \\
\text { (tinggi) }\end{array}$ \\
\hline Menulis/menjelaskan & $\begin{array}{l}53,47 \\
\text { (sangat } \\
\text { rendah) }\end{array}$ & $\begin{array}{l}64,52 \\
\text { (rendah) }\end{array}$ \\
\hline Representasi & $\begin{array}{l}60,42 \\
\text { (rendah) }\end{array}$ & $\begin{array}{l}69,35 \\
\text { (sedang) }\end{array}$ \\
\hline
\end{tabular}

Berdasarkan tabel diatas dapat diketahui bahwa aspek yang paling dominan adalah aspek membaca gambar dengan nilai rata-rata siswa 78,81 (sedang) untuk siklus I dan 82,98 (tinggi) untuk siklus II. Sedangkan aspek yang paling minimal adalah aspek menulis/menjelaskan dengan nilai rata-rata siswa 53,47 (sangat rendah) untuk siklus I dan 64,52 (sedang) untuk siklus II.

Jika kita bandingkan nilai rata-rata yang diperoleh siswa untuk masing-masing aspek tersebut sudah terjadi peningkatan antara siklus I dan II akan tetapi, pada aspek menjelaskan kemampuan rata-rata siswa masih dikategorikan rendah hal ini dikarenakan banyak nya siswa yang tidak memberikan argumentasinya sesuai dengan apa yang diminta dalam tes kemampuan komunikasi matematis. Untuk aspek membaca gambar kemampuan siswa sudah dapat dikategorikan tinggi. Dengan demikian dalam penelitian ini aspek yang paling dominan dalam peningkatan kemampuan komunikasi matematis siswa adalah aspek membaca gambar matematika.

\section{Observasi Siswa Pada Pembelajaran Kooperatif Tipe Match Mine}

Keberhasilan peserta didik dalam belajar tidak hanya dilihat dari keberhasilan siswa dalam menuntaskan materi tetapi yang terpenting adalah bagaimana proses penuntasan materi itu dilakukan. Artinya keterlibatan siswa dalam belajar sangat penting sekali untuk diperhatikan. Pada konsep ini siswa dituntut sebagi orang yang

Doriyani Nasution, Izwita Dewi. 2015. Penerapan Model Pembelajaran Kooperatif Tipe Match Mine untuk Meningkatkan Kemampuan Komunikasi Matematis Siswa Kelas VII di MTs Negeri 2 Medan T.A. 2014/2015. Inspiratif. Vol. 1 No. 1, hal 96-111 
aktif dalam mengkonstruksi pengetahuannya melalui aktivitas siswa untuk mengevaluasi sendiri hasil pembelajaran yang telah dilakukan dan aktivitas mandiri untuk melaksanakan kegiatan semacam tes, dan tugas - tugas yang harus dikerjakan.

Berdasarkan hasil observasi terhadap kegiatan siswa selama pembelajaran kooperatif tipe Match Mine pada siklus I dan siklus II diketahui terjadi peningkatan ratarata siswa dari berkategori cukup menjadi kategori baik. Sejalan dengan meningkatnya keaktifan siswa pada pembelajaran kooperatif tipe Match Mine membuat kemampuan komunikasi matematis siswa dan ketuntasan belajar siswa meningkat juga.

Dari hasil observasi juga diketahui bahwa keterlibatan siswa dalam mencari dan memanfaatkan setiap sumber belajar masih berkategori kurang. Sehingga perlu sebuah upaya penyediaan sumber belajar yang dapat menjembatani pengetahuanyang sudah dimiliki siswa dengan pengetahuan yang akan mereka pelajari.

\section{KESIMPULAN}

Berdasarkan hasil analisis data, dapat diambil kesimpulan yaitu :

1. Pada siklus I kegiatan yang dilakukan adalah menerapkan model pembelajaran kooperatif tipe match mine dengan menggunakan alat peraga kartu berwarna, tetapi kemampuan komunikasi matematis siswa pada aspek menjelaskan masih dikategorikan rendah. Oleh sebab itu, dilakukan perbaikan tindakan di siklus II agar kemampuan komunikasi matematis siswa pada aspek menjelaskan meningkat. Adapun tindakan yang dilakukan peneliti adalah dengan memberikan latihan kepada siswa yang banyak meminta siswa untuk memberikan argumentasinya sehingga aspek menjelaskan pada komunikasi matematis siswa dapat meningkat.

2. Skor yang paling tinggi dari aspek komunikasi adalah aspek membaca gambar dan skor yang paling rendah dari aspek komunikasi adalah aspek menjelaskan.

\section{REFERENSI}

Aljupri, (2009), Analisis Kemampuan dan RepresentasiMatematis (suatu design research terhadap siswa di kota Bandung, Laporan Penelitian, Bandung Ambarjaya, Beni.s., (2012), Psikologi Pendidikan dan Pengajaran Teori dan Praktik, CAPS, Jakarta

Ansari, Bansu I., (2009), Komunikasi Matematik, Yayasan Pena, Banda Aceh Arikunto, S., (2010), Prosedur Penelitian, Rineka Cipta, Jakarta

Aunurrahman, (2009), Belajar dan Pembelajaran, Alfabeta, Pontianak Candra, Ade, (2006), Komponen Komponen Komunikasi, http://aurajogja.files.wordpress.com/20 06/09/pengantar-ilmu-komunikasia5.PDF [diakses 30 Maret 2014]

Fakultas Matematika dan Ilmu Pengetahuan Alam Universitas Negeri Medan, (2012), Pedoman Penulisan Proposal dan Skripsi Mahasiswa Program Studi Kependidikan FMIPA Universitas Negeri Medan, FMIPA Unimed

Griffin, Gina, Kids Say-Iwanna Talk About me, http://mathforum.org/ socha [diakses 30 Maret 2014]

Hudojo, Herman, (2005), Pengembangan Kurikulum dan Pembelajaran Matematika, UM PRESS, Malang

Husna, dkk, (2013), Peningkatan Kemampuan Pemecahan Masalah Dan Komunikasi Matematik Siswa SMP Melalui Model Pembelajaran Kooperatif Tipe Think-Pair-Share (TPS), dalam Jurnal Peluang Volume 1 Nomor 2, ISSN 2302-5158

Isjoni, (2011), Cooperatif Learning, Alfabeta, Bandung

Kbbi Online, (2014), Matematis, http://kamusbesarbahasaindones ia.com

[diakses 27 Mei 2014]

Kagan, Miguel, (2009), Match Mine Mathematics, Kagan Publishing

Doriyani Nasution, Izwita Dewi. 2015. Penerapan Model Pembelajaran Kooperatif Tipe Match Mine untuk Meningkatkan Kemampuan Komunikasi Matematis Siswa Kelas VII di MTs Negeri 2 Medan T.A. 2014/2015. Inspiratif. Vol. 1 No. 1, hal 96-111 
Kagan, Spencer, (1989), The Structural Approach Cooperative Learning, dalam jurnal pdf

Kementrian Pendidikan dan Kebudayaan, (2013), Matematika SMP Kelas VII (kurikulum 2013), Kemendikbud, Jakarta

Latifa, (2009), Pengaruh Model Pembelajaran Kooperatif Tipe Match Mine Terhadap Kemampuan Komunikasi Matematik Siswa, Fakultas Ilmu Tarbiyah Dan Keguruan UIN Syarif Hidayatullah, Jakarta

Lindquist, (2010). Komunikasi Matematika. http://Lindquist.wordpress.com/search ?q=komunikasi+matematika [diakses 23maret 2014]

Mahmudi, Ali (2009), Komunikasi Dalam Pembelajaran Matematika, Jurnal MIPA UNHALU Vol 8 No1, ISSN 1412-2318

Nizar, Achmad, (2010), Kontribusi Matematika Dalam Membangun Daya Nalar dan Komunikasi Siswa. Jurnal Pendidikan Inovatif [online] : http://n124.wordpress.com/2007/08/17 /achmadnizar/, [diakses 19 Desember 2013]

Plasma Link Web Services, Glossary Of Instructional Strategies, http://www.beesburg.com/edtools/glos sary.html [diakses 23 Februari 2014]

Sagala, Saiful, (2009), Konsep dan Makna Pembelajaran untuk Membantu Memecahkan Problemtika Belajar dan Mengajar, Alfabeta, Bandung.

Satriawati, Gusni, (2006), Pembelajaran dengan Open Ended Untuk Meningkatkan Pemahaman dan Kemampuan Komunikasi Matematik Siswa SMP dalam Jurnal Algoritma, CeMED Jur.Pend Matematika, Jakarta

Soekino, Bambang, (2008), Membangun Keterampilan Komunikasi Matematika Dan Nilai Moral Siswa Melalui Model Pembelajaran Bentang Pengajen, disampaikan pada Seminar Internasional UIN Syarif Hidayatullah Jakarta pada 28 Oktober 2008, [online], http://rbryans.wordpress.com [diakses 5 April 2014]

Sukino dan Simangunsong W., (2007), Matematika Untuk SMP Kelas VII, Erlangga, Jakarta

Sunyoto dan Fitriatien R.S.,( 2011), Penerapan Strategi TTW Untuk Meningkatkan Komunikasi Matematika Dan Penalaran Siswa Pada Materi Sistem Persamaan Linear Dua Variabel Kelas X TITL SMKN 2 Bangkalan, dalam Seminar Nasional Pendidikan Matematika di Surabaya

Tandiling, edi, (2012), Pengembangan Instrumen Untuk Mengukur Kemampuan Komunikasi Matematik, Pemahaman Matematik, dan Self Regulated Learning Siswa dalam Pembelajaran Matematika di Sekolah Menengah Atas, Jurnal Penelitian Pendidikan UNTAN Vol.13 No.1

Tim Dosen, (2013), Metodologi Penelitian, Universitas Negeri Medan

Trianto, (2011), Mendisain Model Pembelajaran Inovatif-Progresif,kencana, Jakarta

Turmudi, (2009), Taktik Dan Strategi Pembelajaran Matematika (Referensi Untuk Guru SMA/Ma, Mahasiswa, dan Umum Cetakan I), Leuser Cita Pustaka, Jakarta

Turmudi, (2009), Taktik Dan Strategi Pembelajaran Matematika seri 4 (Referensi Untuk Guru Matematika, Cet II), Leuser Cita Pustaka, Jakarta

Umar, Wahid, (2012), Membangun Kemampuan Komunikasi Matematis Dalam Pembelajaran Matematika, dalam Jurnal Ilmiah PRODI STKIP Siliwangi Bandung Vol 1, No. k1

Wijaya, Ariyadi, (2012), Pendidikan Matematika Realistik, Graha Ilmu,Yogyakarta

Doriyani Nasution, Izwita Dewi. 2015. Penerapan Model Pembelajaran Kooperatif Tipe Match Mine untuk Meningkatkan Kemampuan Komunikasi Matematis Siswa Kelas VII di MTs Negeri 2 Medan T.A. 2014/2015. Inspiratif. Vol. 1 No. 1, hal 96-111 